\section{Kaolin-based Particle Film Has No Effect on Physiological Measurements, Disease Incidence or Yield in Peppers}

\author{
V.M. Russo ${ }^{1}$ \\ U. S. Department of Agriculture, Agricultural Research Service, South Central \\ Agricultural Research Laboratory, P.O. Box 159, Lane, OK 74555
}

\author{
J.C. Díaz-Pérez \\ University of Georgia, Coastal Plain Experiment Station, P.O. Box 748, 4604 \\ Research Way, Tifton, GA 31793-0748
}

Additional index words. Capsicum annuum, culture, heat stress, kaolin, particle film, yield

\begin{abstract}
Heat stress can limit yield in pepper (Capsicum spp.), generally through flower and fruit abortion. A kaolin-based particle film, originally developed to protect fruit trees from insects, has been found to reduce temperatures in tissues of plants. A kaolin-based particle film was tested to determine if it could be used to improve yields of pepper in Oklahoma and Georgia. In Oklahoma, seedlings of a bell pepper, 'Jupiter', and a nonpungent jalapeño, 'Pace 103', were transplanted at three progressively warmer planting dates from mid-May to mid-July 2002 and 2003 , that would ensure that inflorescences would be subject to high day and night temperatures and treated with the kaolin-based particle film. Applications were begun as the first flowers were set and continued through the settings of the first three flushes of flowers on a three-times a week schedule, or on an as needed basis, to determine if the kaolin-based particle film improved yield. In Georgia, the bell peppers 'Camelot' and 'Heritage VR' were transplanted on $24 \mathrm{Apr}$. 2003, and treated with the kaolin-based particle film. In addition to yield, physiological measurements and disease incidences were recorded in Georgia. In both locations treatment with water only served as controls. In Georgia, the kaolin-based particle film had no significant effect on net photosynthesis, stomatal conductance, leaf transpiration or leaf temperature, as measured at midday on clear days. In Oklahoma, planting bell pepper after 15 May is not recommended. Planting the nonpungent jalapeño after mid-June can reduce yields. The kaolin-based particle film did not affect yield at either location and is not recommended for use on peppers.
\end{abstract}

Peppers (Capsicum spp.) subjected to heat-induced flower and fruit abortion (Deli and Tiessen, 1969; Dorland and Went, 1947) can have reduced yields. A new technology, developed to limit insect damage in tree fruit, incorporates a kaolin-based particle film spray (Knight et al., 2001; Unruh et al., 2000). It was determined that the particle film also cools tissues and protects plants from extreme heat and ultraviolet radiation(Glenn etal., 1999). When a kaolin-based particle film was applied to tomato plants, fruit development was delayed and yields were not affected (Makus, 2000). This project was undertaken to determine if a commercially available kaolin-based particle film could be used to affect pepper yields in Oklahoma and Georgia. In Oklahoma, peppers were transplanted at times when they would be exposed to heat stress, and an economic evaluation was conducted to determine the value of the crops. In Georgia, effects of the kaolin-based particle film on selected physiological responses, and disease incidence, were determined. Cultivars,

Received for publication 25 June 2004. Accepted for publication 25 July 2004. Financial support for the Georgia portion of the study was provided by the Georgia Agricultural Experiment Station. Thanks are afforded to D. Bertrand and D. Giddings for technical support and to Ben Mullinix for statistical assistance (all of them from the CPES, Univ. of $\mathrm{Ga}$.). Mention of a trademark, vendor, or proprietary product does not constitute a guarantee or warranty of the product by the U.S. Dept. of Agriculture or the Univ. of Georgia and does not imply its approval to the exclusion of other products that may also be suitable.

${ }^{1}$ Corresponding author; e-mail vrusso-usda@lane-ag.org. production methods, and insect and disease control varied at the two locations.

\section{Materials and Methods}

Oklahoma. The experiment was conducted on a Bernow fine-loamy, siliceous, thermic Glossic Paleudalf soil with a $\mathrm{pH}$ of 7 at the South CentralAgricultural ResearchLaboratory, Lane, Okla. The planting area was $25 \times 60 \mathrm{~m}$. Fertilizer was applied preplant and the area at each planting date received the recommended rate of $112 \mathrm{~N}-112 \mathrm{P}-325 \mathrm{~K} \mathrm{~kg} \cdot \mathrm{ha}^{-1}$ (Motes and Roberts, 1994), which was based on the results of soil tests. The source of $\mathrm{N}$ was ammonium nitrate; $\mathrm{P}$ was $\mathrm{P}_{2} \mathrm{O}_{5}$; and $\mathrm{K}$ was muriate of potash. Raised beds ( $20 \mathrm{~cm}$ high and $18 \mathrm{~cm}$ wide) formed from bare soil were oriented east to west on 0.9-m centers. There were three planting dates in each year, 14 May, 11 June and 16 July 2002, and 15 May, 23 June, and 14 July 2003. Plots on beds were $4.6 \mathrm{~m}$ long. Six-week-old greenhouse grown pepper (C. annuum L.) seedlings of ' Jupiter' bell pepper (Twilley, Hodges, S.C.), and a nonpungent jalapeño, 'Pace 103' (Campbell Seeds, Davis, Calif.), were transplanted at each date. Trays in which transplants were produced were $5.5 \mathrm{~cm}$ deep, $34 \mathrm{~cm}$ wide, and $67.5 \mathrm{~cm}$ long with 128 square cells that were $3.5 \mathrm{~cm}$ on each side (Speedling, American Plant Products, Oklahoma City, Okla.).

Transplants were established in beds in single rows with an in-row spacing of $0.46 \mathrm{~m}$ and 10 plants in each plot, using a mechanical transplanter(Holland TransplanterCo.,Holland, Mich.), which provided a population equivalent of 24,216 plants/ha. In addition to the 10 treated plants there were two plants at either end of each plot, and single guard rows on the north and south that ran the entire length of the treatment plots.

Plants were treated with a kaolin-based particle film (Surround; Engelhard Corp., McIntyre, $\mathrm{Ga}$.) at a rate of $82 \mathrm{~kg} \cdot \mathrm{ha}^{-1}$. A suspension was produced with $8.7 \mathrm{~kg}$ of the kaolin material in $100 \mathrm{~L}$ of water to which $45 \mathrm{~mL}$ of M03 surfactant (Engelhard Corp.) was added. The suspension was applied to plants with a backpack sprayer at initiation of first flower buds, with the spray applied to cover the leaves and the emerging or developing flower buds. After the first application the material was applied on a schedule (Monday, Wednesday, Friday) or on an as needed basis that was determined by a visual evaluation of the residual kaolin cover, and continued through production of the first three flushes of flowers. Controls were plants treated with water only. Plants received a minimum of $30 \mathrm{~mm}$ of water per week in the form of precipitation or through drip irrigation with emitters on $0.9-\mathrm{m}$ intervals (T-Tape, Robbins Irrigation, Ruston, La.). The field was scouted to determine levels of insects or disease to determine the necessity for application of pesticides. Ambient day and night temperatures were provided from a weather station located about $100 \mathrm{~m}$ from the field.

The nonpungent jalapeño plants were harvested once when about $5 \%$ of the fruit in a plot were red.Fruit were considered marketable based on criteria provided by the supplier of the seed. Bell pepper plants were harvested three times over 14-d periods, in each planting date, when fruit were at least US Grade \#1 (USDA, 1989). Number and yield of marketable and cull fruit were determined for both cultivars. Fruit were culled if they were undersized based on norms for each cultivar or were misshapen. There was minimal damage due to insects or diseases, and the effect of the particle film on insect damage was not estimated. Average fruit weight was derived mathematically from the total weight and the total number of fruit produced in plots. The pepper types have different growth habits and responses were not directly compared.

For each pepper type the experimental design was a splitplot. The main factor was planting date. The method of application of the kaolin-based particle film was the subplot and application method was arranged in a randomized complete block withineach planting date. Application treatments were replicated three times within each planting date in each year. Data were analyzed with the general linear models procedures in SAS (ver. 8, SAS, Inc., Cary, N.C.). Mean differences were separated using the Ryan-EinotGabriel-Welch multiple range test. In addition, terminal wholesale market prices at the Dallas Terminal Market for bell peppers, averaged over each harvest period for each planting date were accumulated, as well as the at dock price for the nonpungent jalapeños.

Georgia. The experiment was conducted at the Horticulture Farm, University of Georgia, Coastal Plain Experiment Station, Tifton, Ga., during 2003. The soil was a Tifton Sandy Loam 
(a fine loamy-siliceous, thermic Plinthic Kandiudults) with a $\mathrm{pH}$ of 6.5. The experimental plot consisted of 7.6- $\mathrm{m}$ long raised beds $(20 \mathrm{~cm}$ high and $0.9 \mathrm{~m}$ wide) formed from bare soil on $1.8-\mathrm{m}$ centers oriented north to south. Before laying the mulch with a mulch-laying machine, the soil was fertilized with $78 \mathrm{~N}-34 \mathrm{P}-65 \mathrm{~K} \mathrm{~kg} \cdot \mathrm{ha}^{-1}$, using $780 \mathrm{~kg} \cdot \mathrm{ha}^{-1}$ of a $10 \mathrm{~N}-10 \mathrm{P}-10 \mathrm{~K}$ fertilizer. At the same time the mulch (white-on-black, Plastitech, St-Remi, Quebec, Canada) was laid, drip irrigation tape (T-Tape; T-Systems Intl., San Diego, Calif.), with 30.5-cmemitter spacing and a $17 \mathrm{~mL} \cdot \mathrm{min}^{-1}$ emitter flow, was placed 5 $\mathrm{cm}$ deep in the center of each bed.

Six-week-old greenhouse-grown bell pepper seedlings of 'Camelot' (Seminis, Oxnard, Calif.) and 'Heritage VR' (Harris Moran, Modesto, Calif.) were produced in trays (Plant Way, Cambridge, U.K.) that were $5.5 \mathrm{~cm}$ deep, $34 \mathrm{~cm}$ wide, and $67.5 \mathrm{~cm}$ long with 338 square cells that were $2.5 \mathrm{~cm}$ on each side. Transplants were planted on 24 Apr. 2003 using a mechanical transplanter in beds with double rows with a between row separation of $0.36 \mathrm{~m}$, and an in-row spacing between plants of $0.3 \mathrm{~m}$, which provided a population equivalent of 35,880 plants/ha.

After transplanting, $240 \mathrm{~mL}$ of a soluble starter fertilizer solution, consisting of $555 \mathrm{~mL}$ of a $10 \mathrm{~N}$ 14.8P-0K fertilizer mixed in $100 \mathrm{~L}$ of water, was applied directly to the base of each transplant. Three weeks after transplanting, plants were fertilized weekly through the drip system with $\mathrm{N}$ and $\mathrm{K}$ at rates of $1.5 \mathrm{~kg} \cdot \mathrm{ha}^{-1} \cdot \mathrm{d}^{-1}$ at early stages, $1.8 \mathrm{~kg} \cdot \mathrm{ha}^{-1} \cdot \mathrm{d}^{-1}$ during plant and fruit development, and $1.3 \mathrm{~kg} \cdot \mathrm{ha}^{-1} \cdot \mathrm{d}^{-1}$ at late stages of plant development. The total amount of $\mathrm{N}$ and $\mathrm{K}$ received by the plants after transplanting was $153 \mathrm{~kg} \cdot \mathrm{ha}^{-1}$. The rate of irrigation water applied was equal to $100 \%$ of the evapotranspiration, corrected by crop factor. Evapotranspiration and temperature data during the course of the experiment were collected from a nearby weather station.

Plants were treated with the same kaolinbased particle film as above applied at 56 $\mathrm{kg} \cdot \mathrm{ha}^{-1}$, using a suspension of $6 \mathrm{~kg}$ of the kaolin material in $100 \mathrm{~L}$ of water. The suspension was applied weekly to plants for the entire season with a back-pack sprayer starting two weeks after transplanting. Controls were plants treated with water only.

Leaf gas exchange measurements (net photosynthesis, stomatal conductance and transpiration) and leaf temperature were determined with a portable photosynthesis system(LI-6400, LI-COR Inc., Lincoln, Neb.). Gas exchange measurements were conducted under ambient temperature [ 31.0 to $32.5^{\circ} \mathrm{C}$ (28 May) and 35 to $36^{\circ} \mathrm{C}$ (31 May)] and air humidity conditions ( 18 to $26 \mathrm{mmol} \mathrm{H}_{2} \mathrm{O} / \mathrm{mol}$ ) with $\mathrm{CO}_{2}$ concentration set at $400 \mu \mathrm{mol} \cdot \mathrm{mol}^{-1}$ by means of a $\mathrm{CO}_{2}$ mixer and a $\mathrm{CO}_{2}$ tank, and photosynthetically active radiation (PAR) at $2,000 \mu \mathrm{mol} \cdot \mathrm{m}^{-2} \cdot \mathrm{s}^{-1}$ using a red-blue light source (LI-6400-02B; LI-COR, Inc.). Measurements were conducted on clear days (PAR $>1900 \mu \mathrm{mol} \cdot \mathrm{m}^{-2} \cdot \mathrm{s}^{-1}$ ) from 12:00 to 14:00 Eastern Standard Time on 28 and 31 May 2003 , using three developed and fully exposed leaves per experimental plot. Each measurement lasted about 45 to $60 \mathrm{~s}$.

Plants were monitored weekly for symptoms of southern blight (Sclerotium rolfsii Sacc.), tomato spotted wilt, pythium rot (Pythium spp.), or phytophtora blight (Phytophtora capsici Leonian). Todetermine disease incidences, symptomatic plants were tagged and the numbers of symptomatic plants for each disease determined. Samples of symptomatic plants were sent to the disease clinic laboratory (Rural Development Center, Tifton Campus, Univ. of Ga.), to confirm theidentification of the causal agents. Insecticides were applied as needed, based on scouting (1 to 2 times a week) of the plants

Bell peppers were harvested on 23 June and 7 July and graded according to the USDA standards (USDA, 1989). Number and yield of marketable and cull fruit were determined. Among cull fruit, numbers of fruit with symptoms of either blossom-end rot or sun scald were determined. Average fruit weight was derived mathematically from the total weight and the total number of fruit produced in plots. The design was a latin square

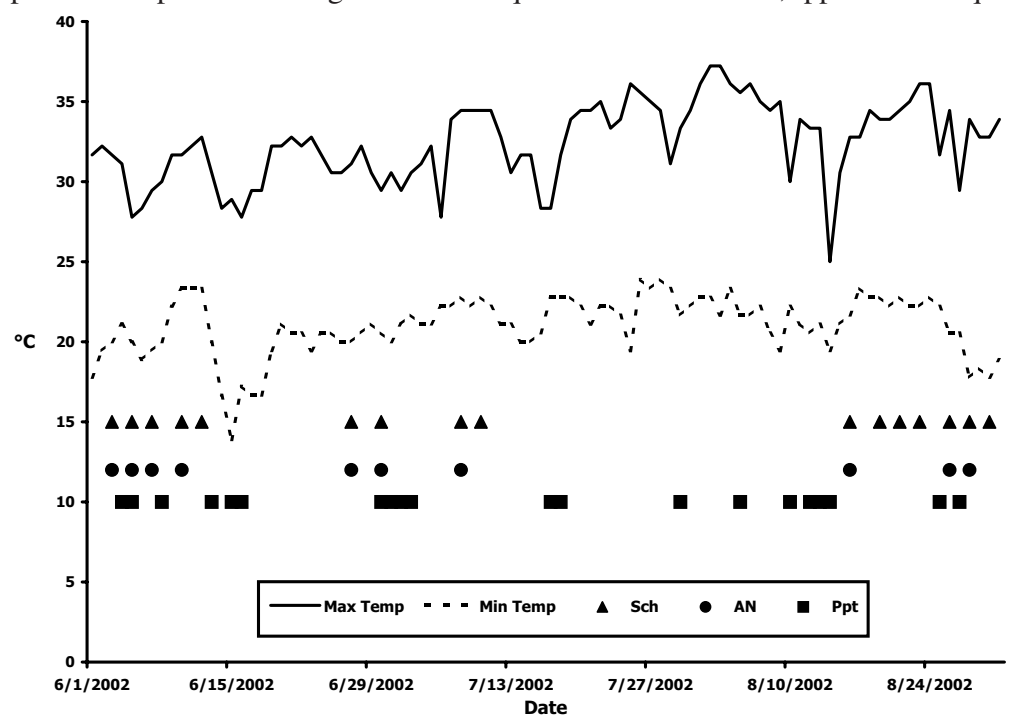

Fig. 1. Maximum and minimum air temperatures, applications of the particle film at scheduled times (Sch), ' $\mathbf{\Delta}$ ', or on an as-needed basis (AN), ' $\bullet$ ', and measurable precipitation events (Ppt), ' $\mathbf{\square}$ ', during the period of setting of the first three flushes of flowers for the three planting dates in 2002 in Oklahoma.

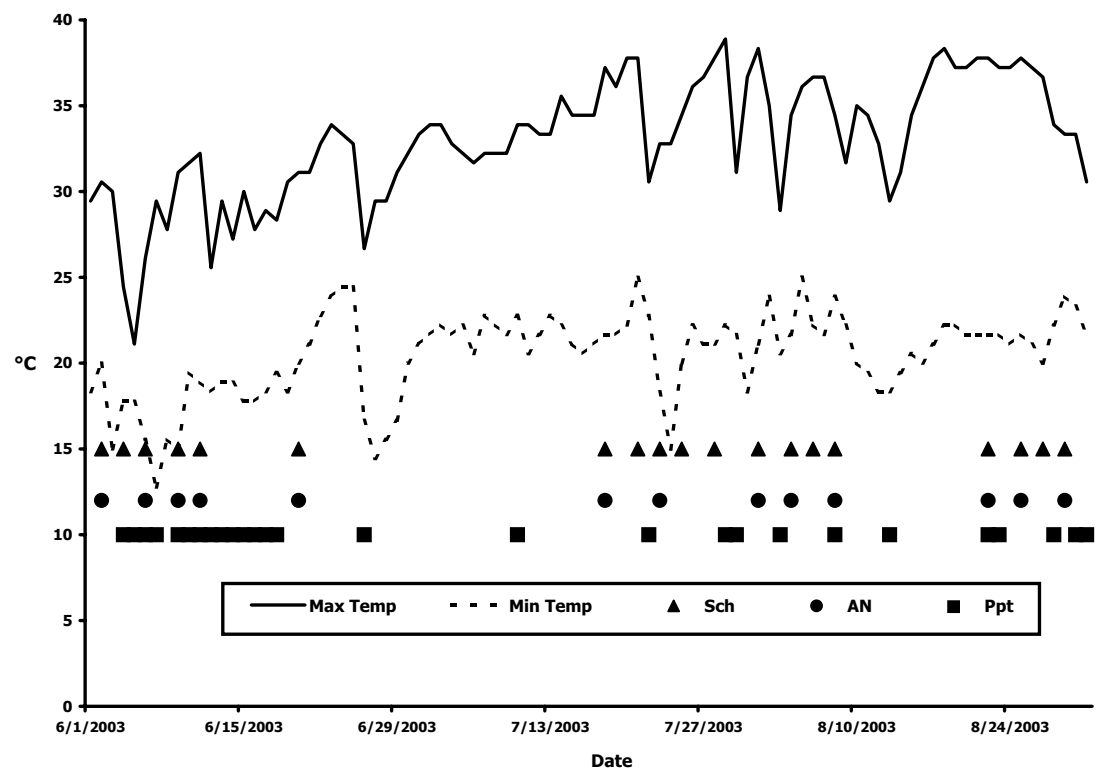

Fig. 2. Maximum and minimum air temperatures, applications of the particle film at scheduled times (Sch), ' $\mathbf{\Delta}$ ', or on an as-needed basis (AN), ' $\bullet$ ', and measurable precipitation events (Ppt), ' $\boldsymbol{\square}$ ', during the period of setting of the first three flushes of flowers for the three planting dates in 2003 in Oklahoma. The extended period between the next to last, and last, applications of the particle film, for the plants of the first planting date, was due to daily rains that would have washed the material off the plants. The last application for that sequence was to try to protect flowers against air temperatures that had been forecast for the upcoming period. 
Table 1. Effect of planting data and application of a kaolin based particle film on yield factors for pepper cultivars in Oklahoma.

\begin{tabular}{|c|c|c|c|c|c|c|c|c|c|c|c|c|}
\hline \multirow[b]{3}{*}{ Source } & \multicolumn{6}{|c|}{ Jupiter } & \multicolumn{6}{|c|}{ Pace103 } \\
\hline & \multicolumn{2}{|c|}{ Marketable } & \multicolumn{2}{|c|}{ Cull } & \multicolumn{2}{|c|}{$\begin{array}{c}\text { Avg } \\
\text { fruit wt }\end{array}$} & \multicolumn{2}{|c|}{ Marketable } & \multicolumn{2}{|c|}{ Cull } & \multicolumn{2}{|c|}{$\begin{array}{c}\text { Avg } \\
\text { fruit wt }\end{array}$} \\
\hline & $\begin{array}{c}\text { No. } \\
(1000 / \mathrm{ha})\end{array}$ & $\begin{array}{c}\text { Yield } \\
\left({\left.\mathrm{Mg} \cdot \mathrm{ha}^{-1}\right)}^{-}\right.\end{array}$ & $\begin{array}{c}\text { No. } \\
(1000 / \mathrm{ha})\end{array}$ & $\begin{array}{c}\text { Yield } \\
\left({\left.\mathrm{Mg} \cdot \mathrm{ha}^{-1}\right)}^{-}\right.\end{array}$ & $\begin{array}{l}\text { Marketable } \\
\text { (g) }\end{array}$ & $\begin{array}{c}\text { Cull } \\
(\mathrm{g})\end{array}$ & $\begin{array}{c}\text { No. } \\
\text { (1000/ha) }\end{array}$ & $\begin{array}{c}\text { Yield } \\
\left({\left.\mathrm{Mg} \cdot \mathrm{ha}^{-1}\right)}^{-}\right.\end{array}$ & $\begin{array}{c}\text { No. } \\
\text { (1000/ha) }\end{array}$ & $\frac{\text { Yield }}{\left({\left.\mathrm{Mg} \cdot \mathrm{ha}^{-1}\right)}^{-1}\right.}$ & $\begin{array}{l}\text { Marketable } \\
(\mathrm{g})\end{array}$ & $\begin{array}{c}\text { Cull } \\
(\mathrm{g})\end{array}$ \\
\hline \multicolumn{13}{|c|}{ (1) } \\
\hline Planting date & $* *$ & $* *$ & NS & NS & NS & NS & $* *$ & $*$ & $* *$ & $* *$ & NS & $* *$ \\
\hline Particle film & NS & NS & NS & NS & NS & NS & NS & NS & NS & NS & NS & NS \\
\hline \multicolumn{13}{|l|}{ Planting date } \\
\hline 14 May & $58.8 \mathrm{~b}^{\mathrm{z}}$ & $7.4 \mathrm{~b}$ & $14.1 \mathrm{a}$ & $1.8 \mathrm{a}$ & $117.9 \mathrm{a}$ & $99.8 \mathrm{a}$ & $534.8 \mathrm{a}$ & $17.0 \mathrm{a}$ & $260.3 \mathrm{~b}$ & $13.9 \mathrm{a}$ & $31.8 \mathrm{a}$ & $9.1 \mathrm{~b}$ \\
\hline 11 June & $92.3 \mathrm{a}$ & $11.9 \mathrm{a}$ & $18.5 \mathrm{a}$ & $1.3 \mathrm{a}$ & $127.0 \mathrm{a}$ & $95.3 \mathrm{a}$ & $447.0 \mathrm{a}$ & $16.1 \mathrm{a}$ & $728.6 \mathrm{a}$ & $3.1 \mathrm{~b}$ & $36.3 \mathrm{a}$ & $18.1 \mathrm{a}$ \\
\hline 16 July & $38.9 \mathrm{~b}$ & $4.9 \mathrm{~b}$ & $14.4 \mathrm{a}$ & $1.2 \mathrm{a}$ & $122.5 \mathrm{a}$ & $86.2 \mathrm{a}$ & $234.1 \mathrm{~b}$ & $8.1 \mathrm{~b}$ & $140.1 \mathrm{~b}$ & $2.7 \mathrm{~b}$ & $36.4 \mathrm{a}$ & $17.9 \mathrm{a}$ \\
\hline \multicolumn{13}{|l|}{2003} \\
\hline Planting date & $* *$ & $* *$ & $* *$ & $* *$ & $* *$ & NS & $* *$ & NS & $* *$ & NS & $*$ & $*$ \\
\hline Particle film & NS & NS & NS & NS & NS & NS & NS & NS & NS & NS & NS & NS \\
\hline \multicolumn{13}{|l|}{ Planting date } \\
\hline 15 May & $55.1 \mathrm{a}$ & $6.7 \mathrm{a}$ & $25.8 \mathrm{a}$ & $2.1 \mathrm{a}$ & $122.5 \mathrm{c}$ & $81.6 \mathrm{a}$ & $267.7 \mathrm{~b}$ & $11.7 \mathrm{a}$ & $211.4 \mathrm{a}$ & $3.5 \mathrm{a}$ & $45.4 \mathrm{~b}$ & $16.8 \mathrm{~b}$ \\
\hline 23 June & $11.5 \mathrm{~b}$ & $1.6 \mathrm{~b}$ & $3.3 \mathrm{~b}$ & $0.3 \mathrm{~b}$ & $140.6 \mathrm{~b}$ & $86.2 \mathrm{a}$ & $318.7 \mathrm{a}$ & $13.1 \mathrm{a}$ & $159.0 \mathrm{~b}$ & $3.7 \mathrm{a}$ & $40.8 \mathrm{~b}$ & $23.6 \mathrm{a}$ \\
\hline 15 July & $19.3 \mathrm{~b}$ & $3.1 \mathrm{~b}$ & $3.2 \mathrm{~b}$ & $0.3 \mathrm{~b}$ & $154.5 \mathrm{a}$ & $104.3 \mathrm{a}$ & $254.5 \mathrm{~b}$ & $13.5 \mathrm{a}$ & $164.5 \mathrm{~b}$ & $3.6 \mathrm{a}$ & $54.4 \mathrm{a}$ & $21.8 \mathrm{a}$ \\
\hline
\end{tabular}

${ }^{2}$ Values in a column followed by the same letter are not significantly different, Ryan-Einot-Gabriel-Welch multiple range test, $P<0.05$.

Ns, ${ }^{* * *}$ Nonsignificant or significant at $P<0.05$ or 0.01 , respectively, by ANOVA. In each year there were no significant interactions.

Table 2. Wholesale market value averaged across particle film treatments for 'Jupiter' bell pepper and the nonpungent jalapeño pepper 'Pace103', in both years in Oklahoma.

\begin{tabular}{|c|c|c|c|c|}
\hline \multirow[b]{3}{*}{ Planting date } & \multicolumn{4}{|c|}{ Value $(\$)$} \\
\hline & \multicolumn{2}{|c|}{2002} & \multicolumn{2}{|c|}{2003} \\
\hline & Jupiter & Pace103 & Jupiter & Pace103 \\
\hline $1^{z}$ & $10,488^{y}$ & 10,200 & 11,079 & 7,020 \\
\hline 2 & 10,307 & 9,660 & 1,260 & 7,860 \\
\hline 3 & 4,246 & 4,860 & 2,685 & 8,100 \\
\hline
\end{tabular}

${ }^{2}$ In 2002 planting dates 1, 2, and 3 are 14 May, 11 June, and 16 July, respectively. In 2003 planting dates 1,2 , and 3 are 15 May, 23 June, and 16 July, respectively.

y Average wholesale prices for 'Jupiter' in 2002 for the 14 May planting was $\$ 18$ and for the 11 June and 16 July plantings was $\$ 11$ per $12.7 \mathrm{~kg}$ carton; and for 'Jupiter' in 2003 for the 15 May planting was $\$ 21$ and for the 23 June and 15 July plantings $\$ 10$ and $\$ 11$, respectively, per $12.7 \mathrm{~kg}$ carton. The wholesale price for 'Pace103' in both years was $\$ 0.60$ per $1 \mathrm{~kg}$.

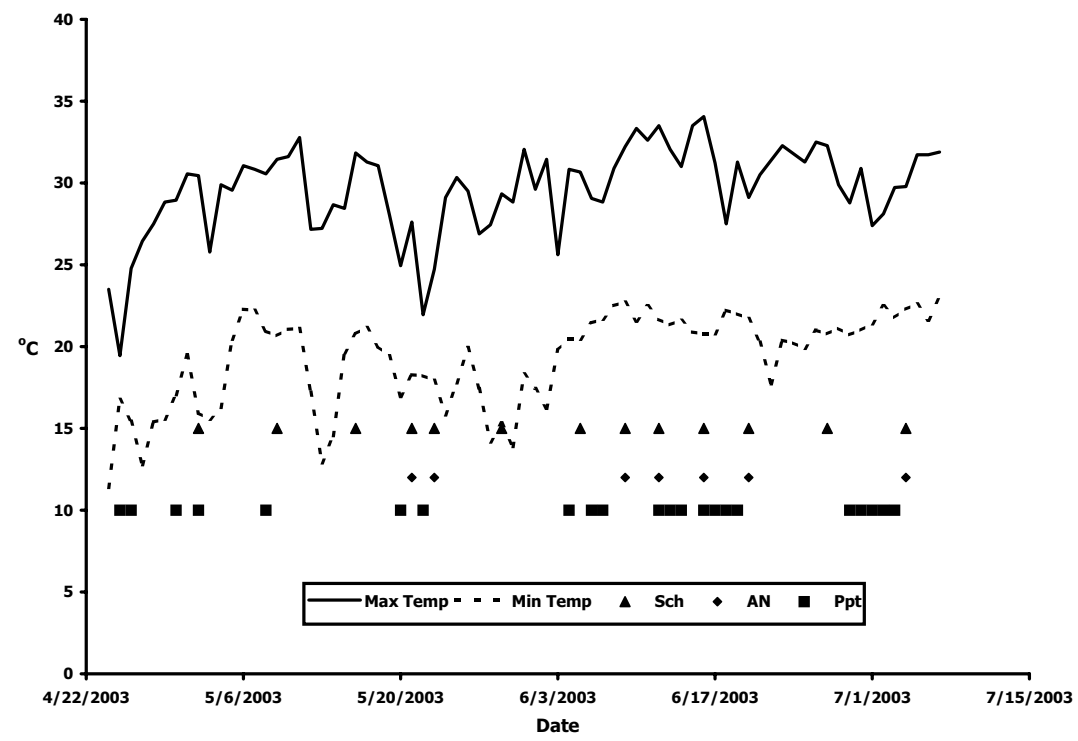

4 (first planting); 4 and 3 (second planting); and 7 and 3 (third planting), respectively. In 2003 , the number of scheduled and as needed applications were 6 and 5 (first planting); 9 and 5 (second planting); and 4 and 3 (third planting), respectively (Figs. 1 and 2).

In both years, yield components were affected only by planting date (Table 1). In 2002, for 'Jupiter', only marketable numbers and yield were affected by planting date with the greatest values occurring for the 11 June planting. Average cull number and yield were 156,667 and 1.4 $\mathrm{Mg} \cdot \mathrm{ha}^{-1}$, and average marketable and cull fruit
In 2003, for 'Jupiter', the greatest marketable and cull number and yield were from the 15 May planting. The highest average marketable and cull fruit weights were from the 15 July planting. The cull fruit weight was not affected by planting date, average 90.7 g. For 'Pace103' the highest number of marketable fruit was from the 23 June planting, but yield (average 12.8 $\mathrm{Mg} \cdot \mathrm{ha}^{-1}$ ) was not affected by planting date. The greatest number of cull fruit was from the 15 May planting date, but yield (average $3.6 \mathrm{Mg} \cdot \mathrm{ha}^{-1}$ ) was not affected by planting date. The highest average marketable fruit weight was from the 16 July planting, and the lowest average cull fruit weight was from the 15 May planting.

In both years the wholesale value for the yields fluctuated with planting date (Table 2). In 2002, the average wholesale market value for 'Jupiter' and 'Pace103' decreased as planting date was later even though the yield was considerably higherfor the second planting date in that year. In 2003, the average wholesale market value for 'Jupiter' from the 15 May planting was 8.8-and 4.1-fold that for the 23 June and 15 July plantings, respectively. In that same year the value of the 'Pace103' yield increased about $13 \%$ from the first to the third planting dates. The income/ha for 'Jupiter' was due to the level of yield and the available price at the wholesale market. For 'Pace103' income/ha was dependent only on yield, the pattern of which was different for the 2 years.

Georgia. The trends of daily temperatures and precipitation events, and dates of application of the kaolin-based particle film, are shown in Fig. 3. There is a higher insect pressure affecting vegetable crops in Georgia and more pesticides were required during the season than in Oklahoma. Plants received eight insecticide applications [carbaryl (Rhone-Poulenc, Research Triangle Park, N.C.), applied 4 times; endosulfan (FMC, Philadelphia, Pa.), applied once; malathion (American Cyanamid, Parsippany, N. J.), applied once; and Spinosad (DowAgroSciences, Indianapolis, Ind.), applied twice] for control of caterpillars and thrips. No pesticides were used to control diseases.

All gas exchange variables except leaf temperature were affected by cultivar, but not by the kaolin-based particle film (Table 3). 'Heritage 
Table 3. ANOVA of effects of cultivar and particle film applications on leaf gas exchange and temperature of bell pepper plants in Georgia.

\begin{tabular}{lcccc}
\hline Source & $\begin{array}{c}\text { Net } \\
\text { photosynthesis } \\
\left(\mu \mathrm{mol} \cdot \mathrm{m}^{-2} \cdot \mathrm{s}^{-1}\right)\end{array}$ & $\begin{array}{c}\text { Stomatal } \\
\text { conductance } \\
\left(\mathrm{mmol} \cdot \mathrm{m}^{-2} \cdot \mathrm{s}^{-1}\right)\end{array}$ & $\begin{array}{c}\text { Transpiration } \\
\left(\mathrm{mmol} \cdot \mathrm{m}^{-2} \cdot \mathrm{s}^{-1}\right)\end{array}$ & $\begin{array}{c}\text { Temp } \\
\left({ }^{\circ} \mathrm{C}\right)\end{array}$ \\
\hline $\begin{array}{l}\text { Cultivar }(\mathrm{C}) \\
\text { Particle film (P) }\end{array}$ & $* *$ & $* *$ & $* *$ & $\mathrm{NS}$ \\
$\begin{array}{l}\text { Cultivar } \\
\quad \text { Camelot }\end{array}$ & $\mathrm{NS}$ & $\mathrm{NS}$ & $\mathrm{NS}$ & $\mathrm{NS}$ \\
$\quad \begin{array}{l}\text { Heritage VR } \\
\text { Particle film }\end{array}$ & $31.4 \mathrm{~b}^{\mathrm{z}}$ & $319 \mathrm{a}$ & $7.2 \mathrm{a}$ & $33.0 \mathrm{a}$ \\
$\quad$ Yes & $39.4 \mathrm{a}$ & $159 \mathrm{~b}$ & $4.7 \mathrm{~b}$ & $33.2 \mathrm{a}$ \\
$\quad$ No & $37.6 \mathrm{a}$ & $257 \mathrm{a}$ & $6.0 \mathrm{a}$ & $32.9 \mathrm{a}$ \\
\hline
\end{tabular}

${ }^{2}$ Values followed by the same letter are not significantly different, Duncan's multiple range test, $P<0.05$.

NS, ${ }^{* *}$ Nonsignificant or significant at $P \leq 0.01$, respectively, ANOVA.

Table 4. Effects of cultivar and kaolin-based particle film on bell pepper yields in Georgia.

\begin{tabular}{|c|c|c|c|c|c|c|}
\hline \multirow[b]{2}{*}{ Source } & \multicolumn{3}{|c|}{ Marketable fruit } & \multicolumn{3}{|c|}{ Culls } \\
\hline & $\begin{array}{c}\text { No. } \\
\text { (1000/ha) }\end{array}$ & $\begin{array}{c}\text { Yield } \\
\left(\mathrm{Mg} \cdot \mathrm{ha}^{-1}\right)\end{array}$ & $\begin{array}{c}\mathrm{Wt} \\
\text { (g/fruit) }\end{array}$ & $\begin{array}{c}\text { No. } \\
\text { (1000/ha) }\end{array}$ & 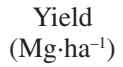 & $\begin{array}{c}\mathrm{Wt} \\
\text { (g/fruit) }\end{array}$ \\
\hline Cultivar & $* *$ & $* *$ & NS & $*$ & NS & NS \\
\hline Particle film & NS & NS & NS & NS & NS & NS \\
\hline \multicolumn{7}{|l|}{ Cultivar } \\
\hline Camelot & $45.7 \mathrm{~b}^{\mathrm{z}}$ & $8.0 \mathrm{~b}$ & $191 \mathrm{a}$ & $18.7 \mathrm{~b}$ & $3.6 \mathrm{a}$ & $137 \mathrm{a}$ \\
\hline Heritage VR & $78.8 \mathrm{a}$ & $17.9 \mathrm{a}$ & $176 \mathrm{a}$ & $28.8 \mathrm{a}$ & $2.5 \mathrm{a}$ & $125 \mathrm{a}$ \\
\hline \multicolumn{7}{|l|}{ Particle film } \\
\hline Yes & $58.9 \mathrm{a}$ & $11.3 \mathrm{a}$ & $189 \mathrm{a}$ & $25.0 \mathrm{a}$ & $3.2 \mathrm{a}$ & $129 \mathrm{a}$ \\
\hline No & $65.6 \mathrm{a}$ & $11.6 \mathrm{a}$ & $177 \mathrm{a}$ & $22.5 \mathrm{a}$ & $2.9 \mathrm{a}$ & $133 \mathrm{a}$ \\
\hline
\end{tabular}

${ }^{2}$ Values followed by the same letter are not significantly different, Duncan's multiple range test, $P<0.05$.

NS,*,**Nonsignificant or significant at $P \leq 0.05,0.01$, respectively, ANOVA. There was not a significant interaction between cultivar and particle film.

VR' had higher net photosynthesis values, and lower values of stomatal conductance and leaf transpiration compared to 'Camelot'. Over particle film treatments values were, on average, $35.4 \mu \mathrm{mol} \cdot \mathrm{m}^{-2} \cdot \mathrm{s}^{-1}, 239 \mathrm{mmol} \cdot \mathrm{m}^{-2} \cdot \mathrm{s}^{-1}$, $6 \mathrm{mmol} \cdot \mathrm{m}^{-2} \cdot \mathrm{s}^{-1}$, and $33.1{ }^{\circ} \mathrm{C}$ for net photosynthesis, stomatal conductance, leaf transpiration and leaf temperature, respectively.

Yield variables were affected only by cultivar (Table 4). 'Heritage VR' produced higher numbers of marketable and cull fruit, and a higher marketable yield than did 'Camelot'. For marketable and cull categories, average fruit weights were similar between cultivars. The number of marketable and cull fruit, and fruit yields, were not affected by the kaolin-based particle film and there was no cultivar $\times$ particle film interaction. The number and weight of fruit with symptoms of sun scald or blossom-end rot were not affected by application of the kaolinbased particle film (data not shown).

'Heritage VR' had a lower ( $0 \%)$ incidence of tomato spotted wilt than 'Camelot' $(4 \%)$, but there were no differences between cultivars in the incidences of the Phytophtora spp. and Phythium spp. complex and southern blight. The incidence of southern blight ( $S$. rolfsii) was lower $(0.5 \%, p<0.05)$ in plants treated with the kaolin-based particle film compared to untreated plants $(6 \%)$, and incidences of tomato spotted wilt $($ mean $=2 \%)$ and the Phytophtora spp. and Phythium spp. complex (mean $=9 \%)$ in kaolin-based particle film treated plants were not different than in untreated plants.

\section{Discussion}

In Oklahoma, yields of bell pepper described different patterns for the 2 years, with lower yields not always associated with later planting. This suggests that environmental stress can occur early as well as later in the year. The reason for the higher yields for bell pepper in the second planting in 2002 in Oklahoma, is notimmediately clear since temperatures during flowering were similar for the three plantings. This suggests that environmental effects over the entire growing season may be more important to yield than conditions occurring only during flowering. Wholesale market prices indicated that planting this bell pepper cultivar through mid-May should provide acceptable returns to the producer. The nonpungent jalapeños appeared to have a better tolerance to environmental stresses when planted through mid-summer. This suggests that this type of pepper can be grown over an entire summer season in Oklahoma, and the market value data indicate they can provide adequate, to good, returns to the producer.

Yields of bell pepper in Georgia were higher than in Oklahoma, and were probably due to cultivar differences and lower temperatures in Georgia (mean $=24.5^{\circ} \mathrm{C}$ ) than in Oklahoma (26.7 ${ }^{\circ} \mathrm{C}$ in 2002 and $26.8^{\circ} \mathrm{C}$ in 2003). Mean air temperatures of 21 to $23^{\circ} \mathrm{C}$ are optimal during vegetative growth and $21^{\circ} \mathrm{C}$ during fruiting of bell pepper under greenhouse conditions (Bakker and van Uffelen, 1988).

In Georgia, use of the kaolin-based particle film did not significantly reduce leaf temperature, and this could explain the limited effect of the kaolin-based particle film on physiological responses. Shading of leaves during measurement of gas exchange variables may have affected leaf temperature. However, as in Table 3, we found no cultivar $\left[26.7^{\circ} \mathrm{C}\right.$ ('Camelot') and 27.0 ${ }^{\circ} \mathrm{C}$ ('Heritage VR')] or kaolin-based particle film effects $\left[27.0{ }^{\circ} \mathrm{C}\right.$ (untreated) and $26.8{ }^{\circ} \mathrm{C}$ (treated)] $(p<0.05)]$ on leaf temperature when canopy temperature was measured by infrared thermometry (12:00 HR, 25 June). Results in Georgia contrast with those of Jifon and Syvertsen
(2003) who found that application of a particle filmdecreased leaf temperatures and increased net photosynthetic and stomatal conductance values under heat stress conditions. The lack of effect of the particle film in Georgia was possibly due of the lower amount of the particle film applied [26 $\mathrm{mL} /$ plant of the kaolin aqueous suspension (rate recommended by the manufacturer)] compared to that of Jifon and Syvertsen ( $300 \mathrm{~mL} /$ plant), even though in the two studies the same concentration of kaolin aqueous suspension was used $\left(60 \mathrm{~g} \cdot \mathrm{L}^{-1}\right)$. Additionally, plants in Georgia were treated with the particle film less frequently (once a week) than those in the study of Jifon and Syvertsen (twice a week).

Effects on yield were consistent in both locations, and were not benefited by use of the kaolin-based particle film. This was true when insecticides were applied, as in Georgia, or not applied, as in Oklahoma. The lack of benefit from use of the kaolin-based particle film on plants in Georgia was also likely due to plants not being exposed to temperatures high enough to result in stress. In Oklahoma, plants were exposed to high day and night temperatures at different planting dates, but there was no benefit to yield due to use of the kaolin-based particle film. It is possible that in Georgia application rates of the kaolin-based particle film may have been too low to produce a significant degree of leaf whiteness, and reduce leaf temperature.

In Oklahoma the kaolin-based particle film was applied to attempt to protect flower and fruit buds from heat induced abortion, but may not have been applied far enough into the growing season. Based on the results the kaolin-based particle film is not recommended for use in production of peppers. However, additional research can be undertaken to determine if variation in rate, or frequency, of application can be used to improve pepper yield.

\section{Literature Cited}

Bakker, J.C. and J.A.M. van Uffelen. 1988. The effects of diurnal temperature regimes on growth and yield of bell pepper. Netherlands J. Agr. Sci. 36:201-208.

Deli, J. and H. Tiessen. 1969. Interaction of temperature and light intensity on flowering of Capsicum frutescens var. grossum cv. California Wonder. J. Amer. Soc. Hort. Sci. 40:493-497.

Dorland, R.E. and F.W. Went. 1947. Plant growth and controlled conditions. VIII. Growth and fruiting of the chili pepper (Capsicum annuum). Amer. J. Bot. 34:393-401.

Glenn, D.M., G.J. Puterka, T. Vanderzwet, R.E. Byers, and C. Feldhake. 1999. Hydrophobic particle films: A new paradigm for suppression of arthropod pests and plant diseases. J. Econ. Entomol. 92:759-771.

Jifon, J.L. and J.P. Syvertsen. 2003. Kaolin particle film applications can increase photosynthesis and water use efficiency of 'Ruby red' grapefruit leaves. J. Amer. Soc. Hort. Sci. 128:107-112.

Knight, A.L., B.A. Christianson, T.R. Unruh, G. Puterka, and D.M. Glenn. 2001. Impacts of seasonal particle films on apple pest management. Can. Entomol. 133:413-428.

Makus, D. 2000. Effect of pre-plant application of VAM and particle film applications on tomato in a supra-optimal, semi-arid environment. HortScience 35:442.

Motes, J. and W. Roberts. 1994. Fertilizing commercial vegetables. Oklahoma State Univ. Agr. Expt. Sta. OSU Extension Facts. F-6000.

United States Department of Agriculture (USDA). 1989. United States standards for grades of sweet peppers. http://www.ams.usda.gov/standards/peperswt.pdf.

Unruh, T.R., A.L. Knight, J. Upton, D.M. Glenn, and G.J. Puterka. 2000. Particle films for suppression of the codling moth (Lepidoptera: Tottricidae) in apple and pear orchards. J. Econ. Entomol. 93:737-743. 